\title{
Latvijas atradņu kvarca smiltis kā pucolāna piedeva betonam
}

\author{
Janina Setina ${ }^{1}$, Vasilijs Akishins ${ }^{2}$, Alona Gabrene ${ }^{3}$, Ieva Ose ${ }^{4}$, \\ ${ }^{1,3,4}$ Riga Technical University, ${ }^{2}$ AS "Nalmieras Stikla šksiedra"
}

\begin{abstract}
Kopsavilkums. Pētītas Latvija devona (Bāles atradne) un juras perioda (Skudras atradne) kvarca smiltis kā dispersās pucolāna piedevas betonam. Veikta abu atradṇu smilšu smalcināšana $\bar{u} d e n s$ vidē, noteikts mineralogiskais, granulometriskais sastāvs un morfologija pirms un pēc smilšu smalcināšanas. Analizēta un izvērtēta dažāda granulometriskā sastāva smilšu pucolānu reakcijas aktivitāte, nosakot to kā brīvā kalcija hidroksīda daudzumu šķīdumā. Analizēts cementa pastas hidratācijas process atkarībā no Skudras un Bāles atradṇu kvarca smilšu dispersitātes un apstrādes laika. Konstatēts, ka augstas dispersitātes Latvijas kvarca smiltīm piemīt pucolāna īpašības, tās veicina cementa pastas hidratācijas procesu un kristālisko kalcija hidrosilikātu veidošanos.
\end{abstract}

Atslēgas vārdi: pucolāna aktivitāte, kvarca smiltis, ķīmiskais, mineralogiiskais sastāvs, dispersitāte.

\section{IEVADS}

Smiltis ir viena no visizplatītākajām minerālām izejvielām Latvijā. Agrāk veiktā Latvijas devona un juras perioda kvarca smilšu ķīmiskā un granulometriskā sastāva analīzē, salīdzinot Ziemel̦eiropas un Baltijas reǵiona kvarca smilšu atradnes un uzñēmumus, kas sagatavo kvarca smilšu izejvielu stikla rūpnīcām, secināts, ka Latvijas kvarca smiltis pēc krāsojošo piemaisījumu samazināšanas, t.i., veicot bagātināšanu, ir perspektīvas pielietošanai stikla rūpniecībā [1,2]. Augstais $\mathrm{SiO}_{2}$ saturs un spēja vienkārši tās bagātināt lauj prognozēt arī kvarca smilšu pielietošanu citās nozarēs, piemēram, būvmateriālu ražošanā.

Betons ir otrs visvairāk patērētais materiāls uz planētas. Tā galvenās sastāvdalias ir saistviela (cements), rupjās un smalkās pildvielas un piedevas. Betona ražošanā dažādas dispersitātes smiltis izmanto gan kā pildvielas, gan kā aktīvas pucolāna piedevas, to piedeva ir neatñemama betona sastāvdal̦a [3-6].

Cementa izgatavošanas procesa lielās energoietilpības dē rodas $5-10 \%$ no pasaules kopējiem $\mathrm{CO}_{2}$ izmešiem. Tādēl pētījumi par jaunu, mazāk energoietilpīgu betonu, kurā galvenā sastāvdaļa ir cements, radīšanu ir sevišķi aktuāli. Viens no šādas problēmas risinājuma veidiem ir cementa satura samazināšana betonā, aizstājot to ar mazāk energoietilpīgiem cementējošiem materiāliem, piemēram, dispersām piedevām - smiltīm ar pucolāna īpašībām. Pucolānu piedevas pievieno betonam salīdzinoši lielos daudzumos, parasti robežās no 20 līdz 70\% no kopējās cementa masas [7].

Jāatzīmē, ka pucolāna īpašības piemīt arī materiāliem, kuri tiek uzskatīti par industriālajiem atkritumiem, kā domnu sārņi, elektrofiltru putekḷi, stikls, biomasas pelni, minerālās izejvielas [ 8-10].
Dispersu pucolāna piedevu izmantošana palielina betona homogenitāti, ilgmūžību, iestrādājamību un stiprību. Nepieciešamo disperso piedevu daudzumu nosaka tā dalinu morfologija, dispersitātes pakāpe. Smalkās piedevas, tai skaitā materiāli ar pucolāna īpašībām, gan paaugstina betona cementējošās îpašības, gan darbojas kā poru aizpildītāji. Pēdējos 50 gados ir veikti daudzi pētījumi, kas saistīti ar pucolānu izmantošanu un piedevu dispersitāti (nanodaļiņu izmantošanu betona izgatavošanā) $[11,12]$. Betona maisījumā pucolānu piedeva palielina $\mathrm{SiO}_{2}$ daudzumu, kas reağē ar hidratācijas procesā cementā radušos $\mathrm{Ca}(\mathrm{OH})_{2}$, veidojot silikātus, savukārt šo daļiņu nano- un mikro- izmērs palielina īpatnējo virsmu [7,13].

Pucolāns ir silikātus vai alumosilikātus saturošs materiāls, kuram piemīt nelielas cementējošas īpašības, bet, kas dispersā veidā - un klātesot mitrumam - ķīmiski reaǵē ar kalcija hidroksīdu, veidojot savienojumus ar cementējošām īpašībām - grūti šksīstošus kalcija silikātus; tāpat var veidoties citi cementa materiāli atkarībā no pucolānu sastāva [12]. Mūsdienās visbiežāk izmantotie pucolāni ir vieglie pelni, silica fume - smalki dispersais silīcija dioksīds (mikrosilika), metakaolīns ar augstu reaǵētspēju, granulētie domnas sārṇi un citi materiāli $[14,15]$.

Dabā sastopamam pucolānam piemīt vairāk vai mazāk cementējošas îpašǐbas, bet bāziskā vidē pēc 28 dienām pucolāns uzrāda labākas cementējošas īpašības. Pieaugošā stiprība tiek izskaidrota ar silīcija dioksīda reakciju ar kal̦kiem, kuras rezultātā veidojas sekundārās cementa fāzes (kalcija silikāta hidrāti ar zemu $\mathrm{Ca} / \mathrm{Si}$ attiecību) un pakāpeniskais īpašîbu (stiprības) uzlabojums parādās parasti pēc 7 dienām. Stiprības attīstības pakāpe ir atkarīga no pucolānu ķīmiskā sastāva: jo augstāks ir silīcija dioksīda un alumīnija oksīda saturs un amorfās dal̦as tajā, jo labāk noris pucolānu reakcijas un ātrāk materiāls uzrāda augstu stiprību [13].

Pucolānu piedevas var darboties 3 veidos: 1) kā pildviela š̄s piedevas/piemaisījumi ir smalkāki nekā cements, tāpēc, pievienojot tās betonam, tiek aizpildītas mazās poras, kas ir vakantas; 2) kā smalka aktīva piedeva - tās paātrina hidratācijas procesu; 3) kā pucolāns - notiekot pucolānu reakcijai [7].

Pucolānu materiāliem tiek uzstādītas vairākas prasības:

- tiem ir jāsatur ķīmiski reaǵētspējīgi silikāti vai alumosilikāti;

- dal̦ināam jābūt smalkām, lai nodrošinātu pietiekamu virsmas laukumu cietvielu reakciju norisei (piedevu normālais virsmas laukums ir $>300 \mathrm{~m}^{2} / \mathrm{kg}$ ); 
- dalināām jāreaǵē ar cementa sastāvdal̦u kalcija hidroksīdu, veidojot savienojumus (kalcija hidrosilikāta gēls, kalcija alumosilikāti u.c.), kuriem piemīt cementējošas īpašības [12].

Lielākā daḷā darbu ir norādīts, ka maksimālais daḷiņu lielums nedrīkst pārsniegt $45 \mu \mathrm{m}$. Tomēr, lai savlaicīgi notiktu reakcija starp $\mathrm{Ca}(\mathrm{OH})_{2}$ no cementa un $\mathrm{SiO}_{2}$ vai alumosilikātiem no pucolāna, ir nepieciešama daļiņu dispersitāte pat $10 . .35 \mu \mathrm{m}[12,13]$.

Cietējot betonam, no cementa izdalās kalkikis, kas reaǵē ar silīcija dioksīdu, veidojot silikātus vai alumosilikātus. Pamatpildviela betona sastāvā ir dažāda granulometriskā sastāva smiltis, kuras galvenā sastāvdaļa ir silīcija dioksīds. Samazinātā zemā virsmas laukuma dēḷ silīcija dioksīds lēni reaǵē ar kalıki, tā rezultātā uz smilšu graudiṇu virsmas veidojas gēls. Šim gēlam piemīt spēja augt, izplesties, un sākuma stadijā tas ir pozitīvi, jo tiek aizpildītas betona tukšās poru vietas, tādējādi novēršot ūdens iekļūšanu un materiāla degradēšanos. Problēma sākas, palielinoties gēla apjomam, kas ir izveidojies pēc betona sacietēšanas. Tas parasti notiek, ja izmanto liela izmēra pucolāna daļinas. N̦emot vērā salīdzinoši nelielo kopējo agregātu virsmas laukumu vai lielu pucolānu daļiņu izmēru, kā arī lēno reakcijas ātrumu starp kaļ̧̧i un silīcija dioksīdu, lielākā gēlu daļa tiek iegūta pēc betona sacietēšanas. Rezultātā iespējama postoša spiediena uzkrāšanās, kas var lēni iznīcināt betonu. Lai to novērstu, pucolāniem ir jābūt lıoti smalkiem $(<10 \mu \mathrm{m})$, lai nodrošinātu lielākās gēlu daḷas veidošanos pirms betona sacietēšanas. Izvēloties optimālu pucolāna daudzumu ar atbilstošu daḷiņu izmēru, tiek panākta betona masas laba sajaukšanās, tiks iegūts sabalansēts un ūdensnecaurlaidīgs mākslīgais akmens $[12,13]$.

Pucolānu reakcijā kal̦kis, kas ir izveidojies $\mathrm{C}_{3} \mathrm{~S}$ $\left(3 \mathrm{CaO} \cdot \mathrm{SiO}_{2}\right)$ un $\mathrm{C}_{2} \mathrm{~S} \quad\left(2 \mathrm{CaO} \cdot \mathrm{SiO}_{2}\right)$ hidratācijas laikā, pārveidojas kalcija silikāta hidrātā (C-S-H). Š̄ reakcija notiek 2 stadijās:

1) cementa hidratācija, kuras laikā veidojas $\mathrm{Ca}(\mathrm{OH})_{2}$

$$
\mathrm{C}_{3} \mathrm{~S}+\mathrm{aq} \rightarrow \mathrm{C}-\mathrm{S}-\mathrm{H}+\mathrm{C}-\mathrm{H}
$$

2) pucolānu reakcija, veidojas kalcija silikāta hidrāti

$$
\mathrm{C}-\mathrm{H}+\mathrm{S}+\mathrm{aq} \rightarrow \mathrm{C}-\mathrm{S}-\mathrm{H}
$$

Pucolānu reakcijas ir lēnas, tāpēc betona stiprības attīstîbas un hidratācijas siltuma pakāpe, kas saistīta ar šo reakciju, arī ir zema. Dažos avotos ir minēts, ka temperatūras pieaugums var paātrināt pucolānu reakciju un attiecīgi arī stiprības attīstību. Pateicoties pucolānu reakcijām, $\mathrm{CH}$ ar zemu blīvumu pārveidojas CSH ar lielāku blīvumu un lielas poras tiek aizpildītas, paliekot porām ar mazāku diametru [16].

Pētot pucolānu reakciju mehānismu, par pucolānu piedevu izmantojot, piemēram, mikro- vai nano- izmēra $\mathrm{SiO}_{2}$, noskaidrots, ka pirmajā stundā, $\mathrm{SiO}_{2}$ saskaroties ar kaļkiem ūdens klātbūtnēe, uz silīcija dioksīda daļiņu virsmas izveidojas gēls, kas ir bagāts ar silīciju un satur maz kalcija. Pēc kāda laika uz silīcija dioksīda virsmas izveidotais gēls sāk šķīst un reaǵē ar kalcija hidroksīdu, veidojot kalcija silikāta hidrātus. Betona izstrādes procesā cementa klātbūtnē iepriekš minētais mehānisms kḷūst sarežǵîtāks. $\mathrm{SiO}_{2}$ uzsūc kaļķ̧os esošo ūdeni, veido ar silīciju bagātu gēlu un patērē lielāko dal̦u no pieejamā ūdens. Betonā bez piedevām porās pēc 3 stundām veidojas atsevišksi kalcija hidroksīda kristāli, bet, izmantojot pucolānu piedevas, izveidojies kaḷkis reaǵē ar silīciju bagāto gēlu, rezultātā veidojos kalcija hidrosilikāti, kurus raksturo augstākas cementējošās īpašības kā kalcija hidroksīdam. Kopējā pucolānu aktivitāte ir saistīta ar silikātu un alumosilikātu saturu amorfajā fāzē, kā arī ar materiālu virsmas laukumu [18].

Dotā darba mērkisis - izvērtēt iespēju izmantot Bāles un Skudru atradṇu kvarca smiltis kā pucolāna piedevas betonam.

\section{MATERIĀLI UN METODES}

Darbā izmantotas divu atradņu smiltis: Juras perioda Skudras atradnes un devona perioda Bāles atradnes kvarca smiltis.

Veikta abu atradņu smilšu smalcināšana, izmantojot planetārās dzirnavas. Malšanas režīmi: 4...6 stundas ūdenī. Apzīmējumi: Bāles atradnes smiltis B-4, B-6; Skudras atradnes smiltis S-4, S-6.

Smilšu granulometriskais sastāvs noteikts, izmantojot lāzera granulometrijas iekārtu CILAS $930 \mathrm{Na} \beta$, mērīšanas diapazons $0.20-500 \mu \mathrm{m}$.

Kvarca smilšu aktīiās virsmas mērījumiem pēc malšanas izmantots slāpekḷa adsorbcijas porozimetrs "Nova 1200 ESeries, Quantachrome Instruments" (porām no 0,35-200 nm).

Betona paraugu sagatavošanai izmantots „AAlborg” firmas baltais cements - CEM I 52,5 R. Cementam pievienots $20 \%$ malto smilšu, paraugi pētīti pēc 60 dienu hidratācijas ūdenī. Darbā izmantoto paraugu izmēri: 40x40x40 mm. Apzīmējumi: paraugi ar Bāles atradnes smiltīm BH- 4, BH- 6, ar Skudras atradne smiltīm SH- 4, SH- 6.

Pucolānu reakcijas aktivitāte novērtēta, analizējot brīvā kalcija hidroksīda $(\mathrm{CH})$ daudzumu šksīdumā [15-16]. Darbā izreaǵējušā pucolāna daudzums tika noteikts, izšks̄īinot paraugu sālsskābē (šajā pārbaudē viss, izṇemot neizreaǵējušo pucolānu, tiek sadalīts pa komponentēm, atbilstoši Massazza M.F. izstrādātajai metodei) [15-18].

Analīzes gaita:

1. Sagatavo kalcija hidroksīdu $\mathrm{Ca}(\mathrm{OH})_{2}-10 \mathrm{~g} \mathrm{Ca}(\mathrm{OH})_{2}$ izšķīdina $200 \mathrm{ml} \mathrm{H} \mathrm{H}_{2} \mathrm{O}$, sakrata un iztur 24 stundas, nofiltrē.

2. Sešās koniskās kolbās iesver pa $1 \mathrm{~g}$ pucolāna parauga, pievieno $100 \mathrm{ml}$ nofiltrēta $\mathrm{Ca}(\mathrm{OH})_{2}$

3. Analizējamos $\mathrm{Ca}(\mathrm{OH})_{2}$ šksīdumus ar disperso $\mathrm{SiO}_{2}$ maisot iztur 3, 24 stundas, 3, 7, 14, 28 dienas.

4. Pēc attiecīgā izturēšanas laika analizējamo šḳīdumu nofiltrē un nosaka kalcija daudzumu šķīdumā.

5. Kalcija noteikšanas analīzes gaita: $25 \mathrm{ml}$ analizējamā šksīduma pievieno $50 \mathrm{ml} \mathrm{H}_{2} \mathrm{O}$ un indikatoru fenolftaleīnu (bezkrāsains pie $\mathrm{pH}<8$, rozā krāsa pie $\mathrm{pH}>8$ ) un titrē ar $0,1 \mathrm{~N} \mathrm{HCl}$, līdz rozā krāsas šķīdums kḷūst bezkrāsains. Paralēli veic trīs analīzes katram paraugam.

6. $\mathrm{Ca}(\mathrm{OH})_{2}$ šksīdumam veic tukšo mēǵinājumu, nosakot kalcija daudzumu tajā.

Pucolāna aktivitāti izsaka kā $\mathrm{CaO}$ daudzuma samazināšanos šksīdumos, salīdzinot ar tukšo analīzi:

$$
\mathrm{CaO}=\left(\mathrm{V}_{1}-\mathrm{V}_{2}^{0}\right) \cdot \mathrm{T}_{1} \cdot \mathrm{k} \cdot \mathrm{B} \cdot 100 / \mathrm{m}, \mathrm{kur}
$$


$\mathrm{V}_{1}$ - titrēšanai izlietotās $\mathrm{HCl}$ daudzums šķīidumam $\operatorname{ar} \mathrm{SiO}_{2}, \mathrm{ml}$ $\mathrm{V}_{2}^{0}$ - tukšā mēǵinājuma titrēšanā izlietotās $\mathrm{HCl}$ daudzums, ml $\mathrm{T}_{1}-0,1 \mathrm{~N} \mathrm{HCl}$ titrs $\mathrm{CaO}(0.0028)$

k - korekcijas koeficients sālsskābes šķ̄ìuma koncentrācijas precizēšanai

$\mathrm{B}$ - visa analizējamā šksīduma tilpuma attiecība pret $\mathrm{CaO}$ noteikšanai n,emtā šks̄iduma tilpumu, ml

$\mathrm{m}$ - analizējamā parauga iesvars, $\mathrm{g}$.

Noteikts kristālisko fāžu sastāvs, izmantojot rentgenstaru difraktometru Rigaku Ultima ${ }^{+}$ar $\mathrm{Cu}_{\mathrm{K} \alpha}$ starojumu. Rentgenogrammas identificētas, izmantojot PDF-4+ 2012 Sleve datu bāzi.

\section{EKSPERIMENTĀLĀ DAḶA}

\section{A. Skudras un Bāles atradņu kvarca smilšu raksturojums}

Iepriekšējos izpētes darbos [1,2] veiktā ķīmiskā analīze parādīja, ka Skudras un Bāles atradņu smiltis raksturo augsts $\mathrm{SiO}_{2}$ saturs - līdz 98\%, bet dalinu izmērs ir 0,1-0,5 mm robežās.

Apstrāde ūden̄̄ planetārās dzirnavās Skudras atradnes smiltīm paaugstināja $\mathrm{SiO}_{2}$ saturu līdz $>99 \%$, vienlaicīgi, samazināja $\mathrm{Fe}_{2} \mathrm{O}_{3}$ daudzumu. Bāles atradnes smiltīm novēroja nelielas dzelzs satura izmainas, bet $\mathrm{SiO}_{2}$ saturs praktiski palika nemain̄̄gs. Ķ̄̄miskā analīze norādīja uz atšksirīgu piemaisījumu raksturu šīm atradņu smiltīm. Noskaidrots, ka Skudras atradnes smiltīm raksturīgs virsmas piemaisījumu veids.

Mazgāšanas laikā ūden̄̄ smilšu izejmateriāla graudiṇi ne tikai tika atbrīvoti no virsmas piemaisījumiem, bet arī būtiski mainījās granulometrija un dalıiņu konfigurācija.

Skudras un Bāles atradņu kvarca smiltis pēc apstrādes ūdenī un malšanas planetārajās dzirnavās var sasniegt pucolāna piedevas mikrosilikas dispersitāti, t.i., 30 - $450 \mathrm{~nm}$ un aktīvo virsmu $7-8,5 \mathrm{~m}^{2} / \mathrm{g}$.

Latvijā betona ražošanā visplašāk pielietotā pucolāna piedeva ir mikrosilika ar dispersitāti $30-450$ nm un aktīvo virsmu $7-8,5 \mathrm{~m}^{2} / \mathrm{g}$. Skudras un Bāles atradṇu kvarca smiltis pēc apstrādes ūden̄̄ un malšanas planetārajās dzirnavās var sasniegt mikrosilikas dispersitāti.

Agrāk veiktā Bāles un Skudras atradņu smilšu granulometriskā izpēte parādīja, ka abas atradnes pieder pie vidējās un smalkās frakcijas smilšu atradnēm, tām raksturīgs neliels smalkās frakcijas daudzums $<0,25 \%$, bet Bāles smiltīm rupjā frakcija $>1 \mathrm{~mm}$ ir $0,85 \%[2,19]$.

Skudru un Bāles atradņu kvarca smilšu graudiṇu īpatnējā virsma pēc 4 un 6 stundu malšanas ievērojami palielinās un pārsniedz šodien izmantotā smilšu pulvera īpatnējās virsmas lielumus (1. tabula).

1.attēlā parādītas SEM mikrofotogrāfijas Skudras un Bāles atradņu kvarca smilšu graudiņiem pēc malšanas. Smilšu graudinu virsma pirms apstrādes abos gadījumos ir heterogēna, bet Bāles atradnes smilšu graudiṇiem novērojama zvīņveida virsma, kas saistīta ar piemaisījumu esamību uz virsmas. Piemaisījumus iespējams viegli atdalīt, smalcinot smiltis ūden̄̄ un tādā veidā paaugstinot $\mathrm{SiO}_{2}$ saturu [1,2]. Pēc 4 un 6 stundu malšanas ieguva plākšñainus graudus, kas imitē kvarca kristāla struktūru.
1. TABULA

KVARCA SMILŠU GRAUDIN̦U İPATNĒJĀ VIRSMA

\begin{tabular}{|l|c|c|c|}
\hline \multicolumn{1}{|c|}{ Smilšu atradne } & $\begin{array}{c}\text { Piegādātais, } \\
\mathrm{m}^{2} / \mathrm{g}\end{array}$ & $\begin{array}{c}\text { Maltas } 4 \mathrm{st} . \mathrm{H}_{2} \mathrm{O} \\
\mathrm{m}^{2} / \mathrm{g}\end{array}$ & $\begin{array}{c}\text { Maltas 6 st. } \mathrm{H}_{2} \mathrm{O} \\
\mathrm{m}^{2} / \mathrm{g}\end{array}$ \\
\hline $\begin{array}{l}\text { 1. Smilšu } \\
\text { pulveris }\end{array}$ & 0.91 & - & - \\
2. Bāles & & 1.176 & 3.19 \\
3. Skudras & - & 1.689 & 2.071 \\
\hline
\end{tabular}

*Betona ražošanā izmantojamā dispersā piedeva

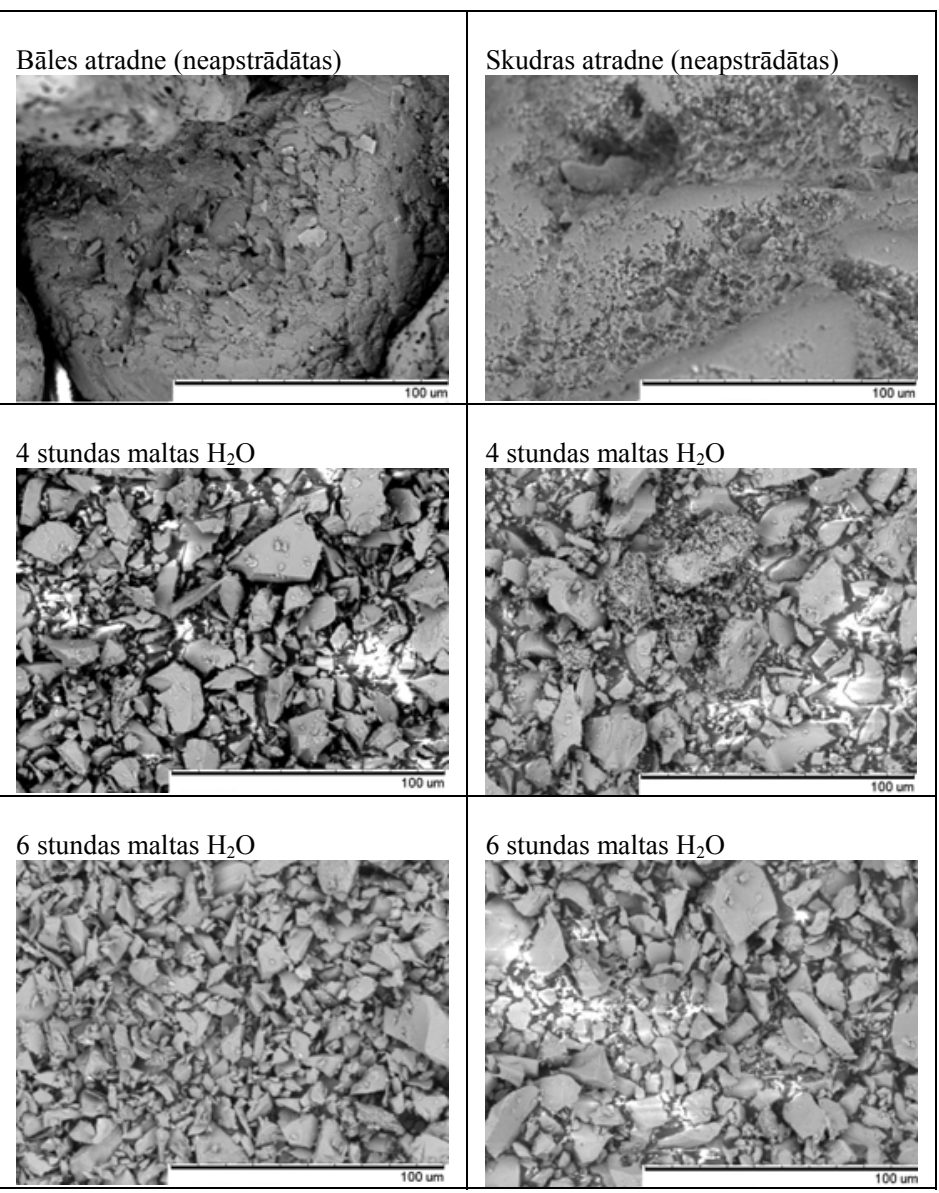

1. att. SEM mikrofotogrāfijas Bāles un Skudras atradṇu kvarca smiltīm.

Izmantojot slāpekḷa adsorbcijas porozimetru, maltām smiltīm uzṇemtas adsorbcijas un desorbcijas līknes, kuras norādīja uz Bāles atradnes smilšu lielāku īpatnējo virsmu (2. attēls). Adsorbcijas un desorbcijas līkṇu raksturs un gaita praktiski ir analoǵisks, kas saistāms ar daļinu kristāliskumu.

2. tabulā un 3.-5. attēlos dotās histogrammās parādīta smilšu dispersitāte pēc malšans ūdenī dažādos režīmos. Redzams, ka pēc malšanas ūdens vidē, kas intensificē malšanās procesu, abu atradņu smiltīm iegūti praktiski analogiski rezultāti, t.i., graudu vidējais izmērs pēc 4 stundu apstrādes ir robežās

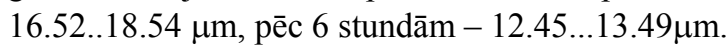




\section{TABULA}

BĀLES UN SKUDRAS ATRADN̦U SMILŠU GRANULOMETRISKAIS SASTĀVS PĒC MALŠANAS DAŽĀDOS REŽĨMOS, MAS.\%

\begin{tabular}{|l|l|l|l|l|}
\hline Paraugs & $\begin{array}{c}\text { Daudzums } \\
10 \%, \mu \mathrm{m}\end{array}$ & $\begin{array}{c}\text { Daudzums } \\
50 \%, \mu \mathrm{m}\end{array}$ & $\begin{array}{c}\text { Daudzums } \\
90 \%, \mu \mathrm{m}\end{array}$ & $\begin{array}{c}\text { Vidējais } \\
\text { izmērs, } \mu \mathrm{m}\end{array}$ \\
\hline Bāles & 2.08 & 13.19 & 35.61 & 16.52 \\
B-4 & 1.55 & 9.08 & 29.02 & 12.45 \\
B- 6 & & 15.67 & 39.14 & 18.54 \\
\hline Skudru & 2.30 & 9.76 & 30.86 & 13.49 \\
S- 4 & 1.82 & \multicolumn{3}{|l}{} \\
S- 6
\end{tabular}

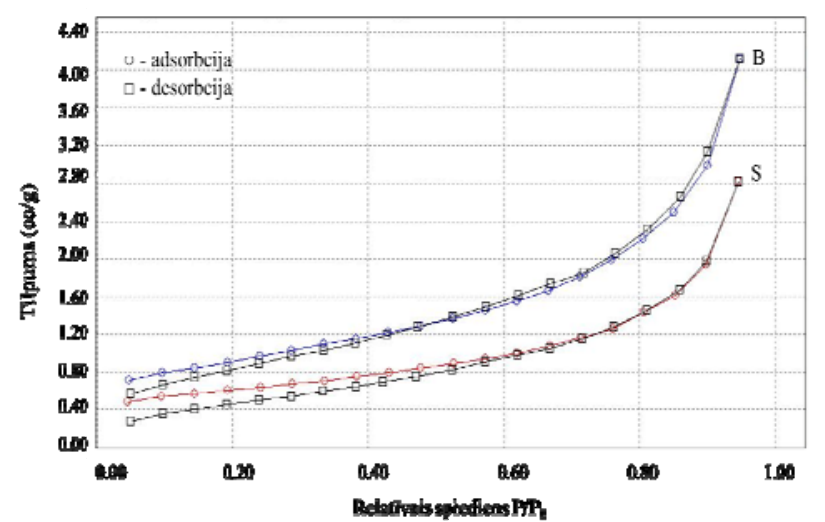

2. att. Bāles (B) un Skudras (S) atradņu kvarca smilšu adsorbcijas un desorbcijas līknes pēc 6 stundu malšanas ūdenī.

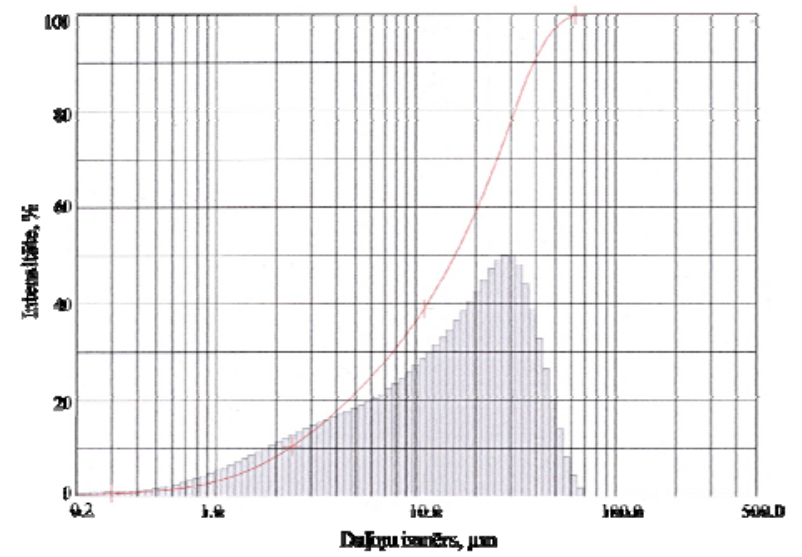

3. att. Skudras atradnes 4 stundas ūdenī malto smilšu histogramma.

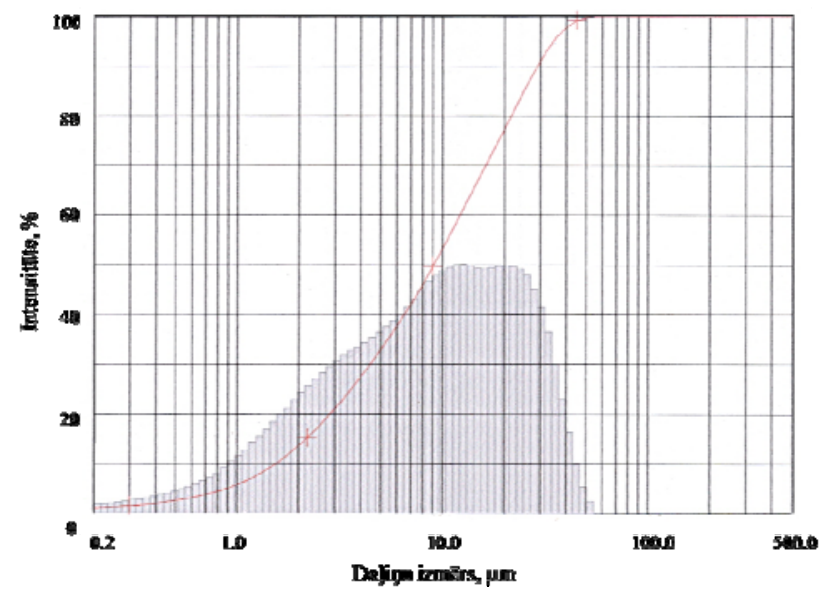

4. att. Skudras atradnes 6 stundas ūdenī malto smilšu histogramma.

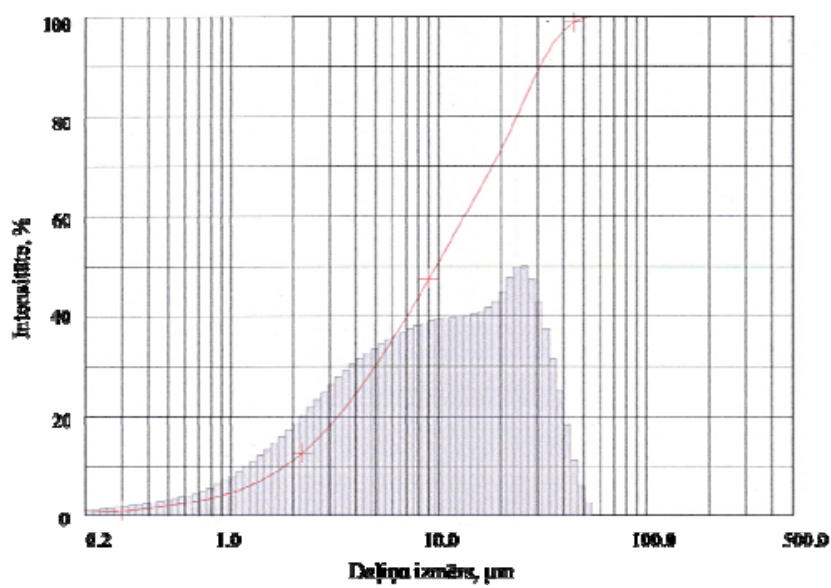

5. att. Bāles atradnes 6 stundas ūdenī malto smilšu histogramma.

\section{B. Skudras un Bāles atradņu kvarca smilšu kā pucolāna piedevu raksturojums}

Malto smilšu aktivitātes novērtēšanai, veikts iegūto smilšu pucolāna aktivitātes tests, kur atbilstoši augstāk aprakstītai metodikai, aktivitāti raksturo kā $\mathrm{SiO}_{2}$ spēju reaǵēt ar $\mathrm{Ca}(\mathrm{OH})_{2}$ šksīdumu, izsakot kā reaktīvā $\mathrm{CaO}$ (mas. \%) daudzumu.

3. TABULA

PUCOLĀNA AKTIVITĀTE (REAKTĪVĀ CAO MAS.\% DAUDZUMS) UN SPECIFISKĀ AKTĪVĀ VIRSMA

\begin{tabular}{|c|c|c|c|c|}
\hline Paraugs & $\begin{array}{c}\text { Reaktīvā CaO } \\
\text { daudzums pēc } \\
\text { 3 dienām, } \\
\text { mas.\% }\end{array}$ & $\begin{array}{c}\text { Reaktīvā } \\
\text { CaO } \\
\text { daudzums } \\
\text { pēc 7 } \\
\text { dienām, } \\
\text { mas.\% }\end{array}$ & $\begin{array}{c}\text { Reaktīiāa } \\
\text { CaO } \\
\text { daudzums } \\
\text { pēc 14 } \\
\text { dienām, } \\
\text { mas.\% }\end{array}$ & $\begin{array}{c}\text { Specifiskāa } \\
\text { aktīvā } \\
\text { virsma, } \\
\mathrm{m}^{2} / \mathrm{g}\end{array}$ \\
\hline $\begin{array}{c}\text { Smilšu } \\
\text { pulveris }\end{array}$ & 1.299 & 1.473 & 1.422 & 0.91 \\
\hline $\begin{array}{c}\text { Bāles } \\
\text { B-4 }\end{array}$ & 1.65 & 1.67 & 1.65 & 1.176 \\
B-6 & 1.73 & 1.69 & 1.72 & 3.19 \\
\hline $\begin{array}{c}\text { Skudru } \\
\text { S-4 }\end{array}$ & 1.833 & 1.851 & 1.99 & 1.687 \\
S-6 & 1.971 & 2.03 & 2.234 & 2.071 \\
\hline
\end{tabular}

*Betona ražošanā izmantojamā dispersā piedeva

3. tabulas dati parāda, ka Bāles un Skudras atradnes malto smilšu pucolāna aktivitāte pieaug līdz ar aktīvās virsmas palielināšanos, tas ir, ar dispersitāti. Skudras atradnes smiltis raksturo augstāks reaktīvā $\mathrm{CaO}$ daudzums, kas pieaug, pagarinot smilšu apstrādes laiku $\mathrm{Ca}(\mathrm{OH})_{2}$ šķ̄idumā. $\mathrm{SiO}_{2}$ dalıināam kalcija hidroksīda ūdens šķīdumā uz virsmas veidojas gēls, kas šḳīst un reaǵē ar sārmu. Nelielais reaktīvā $\mathrm{CaO}$ daudzuma pieaugums laika periodā no 3 līdz 14 dienām parāda, ka reakcijas spējīgā silīcija dioksīda gēla kārta izveidojas 3-7 dienās un, gēla dạ̦iņu aglomerācijas dēḷ, reakcija ar sārmu turpmāk tiek ierobežota.

Izpētes turpinājumā izveidoti cementa pastas paraugi, kuros smalkās Bāles un Skudras atradnes smilšu piedevas daudzums ir 20\%. Pēc 60 dienu hidratācijas pētīta paraugu mikrostruktūra un noteikts paraugu kristāliskais sastāvs.

Mikrostruktūra cementa pastas hidratētiem paraugiem ar Bāles, Skudras atradņu un smilšu pulvera piedevu parādīta 6. attēlā. Pēc 60 dienu hidratācijas SEM attēlos uz cementa 
graudiniem ar Bāles smilšu piedevu tika konstatēta amorfas gēlveida kārtinas veidošanās un diegveida veidojumi, kas liecina par kristāliskā $\mathrm{Ca}(\mathrm{OH})_{2}$ klātbūtni. Paraugiem ar Skudras atradnes smiltīm tika novērota atšķirīga mikrostruktūra. Līdzās amorfai sastāvdal̦ai redzami izteikti kristāliski veidojumi, kas raksturīgi kalcija hidrosilikātiem [17]. Paraugu ar Skudras atradnes disperso smilšu piedevu mikrofotogrāfijas parādīja, ka šìm smiltīm piemīt pucolāna ippašības. Kalıkis no cementa reaǵē ar silīciju bagāto gēlu uz smilšu dal̦ināām, veidojot kristāliskos kalcija hidrosilikātus, tādā veidā paaugstinot betona cementējošās īpašības.

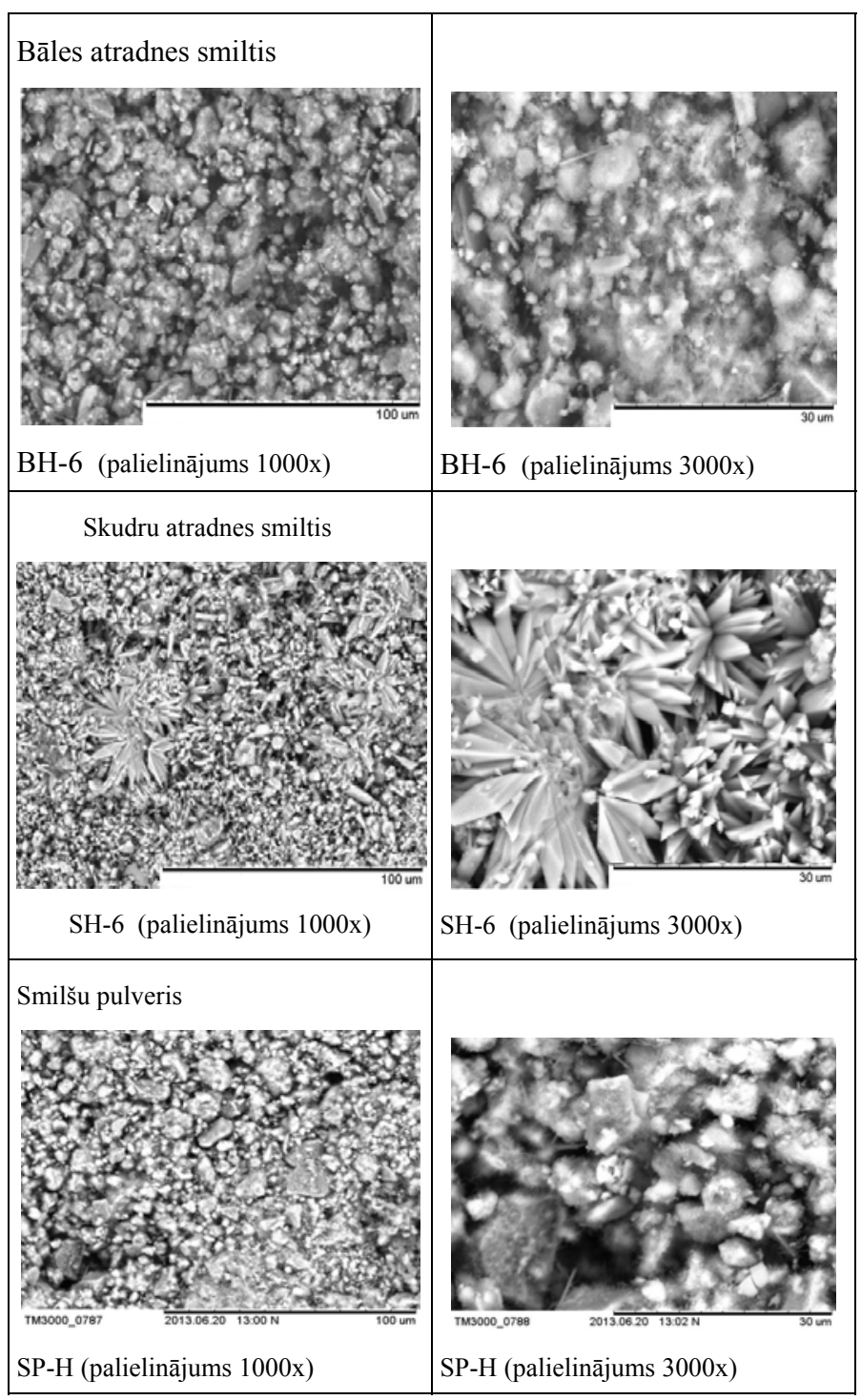

6. att. SEM mikrofotogrāfijas paraugiem SP-H, BH-6 un SH-6 pēc 60 dienu hidratācijas.

SEM mikrofotogrāfijās cementa pastai ar šodien betona ražošanai izmantotā smilšu pulvera piedevu redzams, ka hidratācijas procesā pēc 60 dienām veidojas gēlveida kārtiṇa, bet attēlā nav cementa un silīcija dioksīda gēla kārtinas mijiedarbības produktu. Mazās specifiskās aktīvās virsmas $\left(0.91 \mathrm{~m}^{2} / \mathrm{g}\right)$ dēl pētîtajam smilšu pulverim nepiemīt cementējošās pucolāna īpašības, tas darbojas tikai kā poru aizpildītājs.
Rentgendifraktogrammās (skat. 7.attēlu) konstatētas sekojošas kristāliskās fāzes: kvarcs un cementā esošie minerāli kalcīts $\mathrm{CaCO}_{3}$ un portlandīts $\mathrm{Ca}(\mathrm{OH})_{2}$. Abos paraugos konstatēti difrakcijas maksimumi, kas norāda uz kalcija hidrosilikāta tobermarīta veidošanos. Tātad Bāles un Skudras atradṇu maltās smiltis darbojas kā pucolāna piedeva un veicina kalcija hidrosilikāta veidošanos. Paraugos ar smilšu pulvera piedevu nav konstatēta tobermarīta veidošanās.

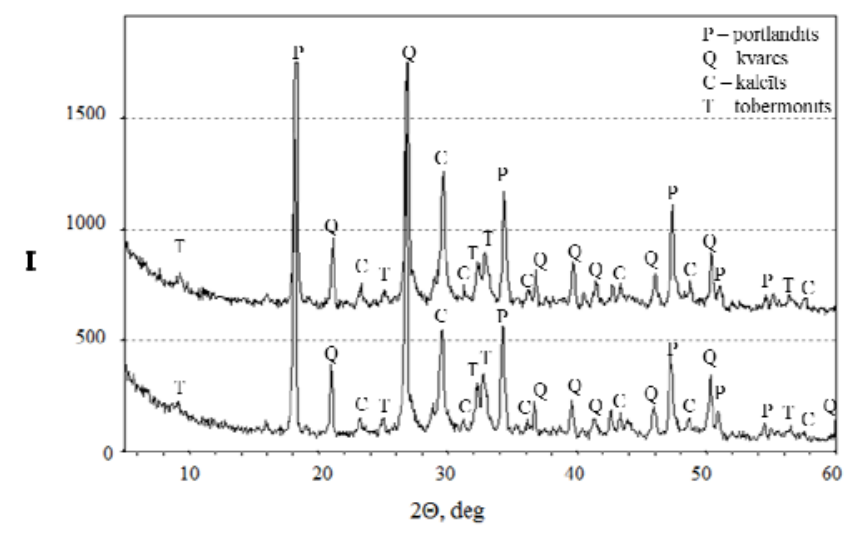

7. att. Rentgendifraktogrammas paraugiem SH-6 (1) un BH-6 (2) pēc 60 dienu hidratācijas.

\section{SECINĀJUMI}

Darbā pētīta iespēja izmantot Latvijas devona perioda Bāles atradnes un juras perioda Skudras atradnes kvarca smiltis kā pucolāna piedevu betona ražošanā. Skudras un Bāles atradṇu kvarca smiltīm pētīta sakarība: smalcināšanas laiks dispersitāte - graudiṇu specifiskā aktīvā virsma - pucolāna aktivitāte. Smilšu specifiskā aktīvā virsma pēc smalcināšanas ievērojami palielinās līdz $3.19 \mathrm{~m}^{2} / \mathrm{g}$ un pārsniedz šodien betona ražošanā izmantotā smilšu pulvera îpatnējās virsmas lielumu $\left(0.91 \mathrm{~m}^{2} / \mathrm{g}\right)$.

Bāles un Skudras atradṇu maltām kvarca smiltīm $\mathrm{N}_{2}$ gāzes adsorbcijas un desorbcijas līknu raksturs un gaita praktiski ir analogiska, histerēzes cilpas veids norāda uz daḷinu kristāliskumu. SEM mikrofotogrāfijās pēc 4 un 6 stundu smalcināšanas konstatēti plākšn,veida graudiṇi, kas imitē kvarca kristāla struktūru.

Abu atradṇu smilšu dispersitāte pēc malšanas ūden̄̄ dažādos režīmos ir analoǵiska, t.i., graudu vidējais izmērs pēc 4 stundu

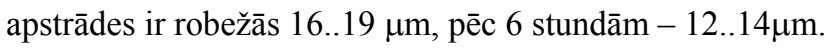

Malto smilšu pucolāna aktivitātes novērtēšanai, veikts pucolāna aktivitātes tests, kas parādīja, ka Bāles un Skudras atradņu malto smilšu pucolāna aktivitāte pieaug līdz ar specifiskās aktīvās virsmas palielināšanos, tas ir ar dispersitāti. Skudras atradnes smiltis raksturo augstāka pucolāna aktivitāte. Nelielais reaktīvā $\mathrm{CaO}$ daudzuma pieaugums laika periodā no 3 līdz 14 dienām parāda, ka reakcijas spējīgā silīcija dioksīda gēla kārta uz smilšu graudiniem izveidojas 3-7 dienās un gēla dal̦iṇu aglomerācijas dēḷ reakcija ar sārmu turpmāk tiek ierobežota.

Morfologijas un kristālisko fāžu pētījumi cementa pastām ar maltām Latvijas smiltīm hidratācijas procesā parāda, ka smiltis ar graudu izmēru 12..14 $\mu \mathrm{m}$ darbojas gan kā poru aizpildītāji, gan kā cementējošās pucolāna piedevas, veicinot kalcija hidrosilikātu veidošanos. 


\section{LITERATŪRAS SARAKSTS}

[1] Sētiṇa, J., Akišins, V. Latvijas kvarca smiltis stikla ražošanai, RTU zinātniskie raksti. Materiālzinātne un lietišķā ķīmija. 24. sēj., 2011, 61.70. lpp.

[2] Sētiņa, J., Akišins, V., Kirilova, S. Bāles un Skudras atradņu kvarca smilšu izpēte, RTU zinātniskie raksti. Materiālzinātne un lietišķāa ķīmija. 26. sēj., 2012, 88.-96. lpp.

[3] Mehta, P.K., P.J.M. Monteiro, P.J.M., Concrete: Microstructure, Properties, and Materials, 3rd Edition, McGraw-Hill, 2006, 387p.

[4] Donza, H., Cabrera, O., Issarar, E.F.. High-strength concrete with different fine aggregate. Cem. Concr. Res., 2002, 32, pp.1755-1761. http://dx.doi.org/10.1016/S0008-8846(02)00860-8

[5] ACI E4, Chemical Admixtures for Concrete, ACI Education Bulletin E4-03, American Concrete Institute, Farmington Hills. Michigan, 2003, $12 \mathrm{p}$.

[6] Edmeades, R.M., Hewlett, P.C. Cement admixtures. Lea's Chemistry of Cement and Concrete. $4^{t 4}$ ed., Peter C.Hewlett edt., Elsevier, 2006, pp. 843-863.

[7] Taylor, H.F.W. Cement Chemistry (2nd edn), Thomas Telford Publishing, London, 1997. http://dx.doi.org/10.1680/cc.25929

[8] Cook D.J. Natural pozzolanas. In: Swamy R.N., Editor Cement Replacement Materials, Surrey University Press, 1986, 200 p.

[9] McCann, A.M. The Roman Port of Cosa 273 BC, Scientific American, Ancient Cities, 1994, 92-99.

[10] http://www.naturalpozzolan.com (lapa skatīta 12.06.13)

[11] Malhotra, V.M., Kumar Mehta, P. Pozzolanic and cementitious materials. Series: Advances in concrete technology, Amsterdam: Gordon and Breach cop., 1996.

[12] Mindess, S., Skalny, J. (Editors) Materials Science of Concrete 6. The American Ceramic Society: Westerville, 2006, pp. 353-371.

[13] Newman, J., Choo Bang Seng (edited), Advanced Concrete Technology. Constituent Materials, Vol.1., Elsevier, Butterworth Heinemann, 2003, 270p

[14] Shi Caijun, Kvivenko, P.V., Roy Della. Alkali-Activated Cements and Concretes, Taylor \& Francis, 2006, 376 p..

[15] Massazza, M.F. Structure of pozzolana and fly-ash and the hydratation of pozzolanic and fly ash cements. 7th Tnt. Congr. on Chem. of Cem., Paris, 1980, Proc.: vol 4, p. 85-91, Paris 1981.

[16] Massazza, M.F.; Costa, U., Aspects of the pozzolanic activity and properties of pozzolanic cements, Il. Cemento 76, 1976, p. 3-18.
[17] Stepkowska, E.T., et. al. Hydration products in two aged cement pastes, J. of Thermal Anal. and Calor., vol. 82, 2005, pp. 731-739. http://dx.doi.org/10.1007/s10973-005-0957-2

[18] Lodeiro, G.I., Macphee, D.E., PalomoO, A., Fernandez-Jimenez, A., Effect of alkalis on fresh $\mathrm{C}-\mathrm{S}$-H gels. FTIR analysis, Cem. and Concr. Research, vol 39, 2009, pp. 143-147.

[19] Sedmalis, U., Šperberga, I. Mineralogíija, Rīga: Rīgas Tehniskā universitāte, 2005, 268 lpp.

Janina Setina. 1977 - Dr.sc.ing., Riga Politechnical Institute (since 1992 Riga Technical University).

Work experience - since 1972 - Riga Technical University, Institute of Silicate Materials - senior research scientist, docent; since 1999 - Head of the Testing laboratory of Silicate Materials.

Autors of 133 scientific publications; supervisor of bachelor, master, doctoral students.

janina@ktf.rtu.lv

Vasilijs Akishins. 1998 - Dr.sc.ing., Riga Technical University.

Work experience - since 1998 - Valmieras stikla šķiedra AS, Latvia (Valmiera glass fiber JSC plc) - glass technologist; simultaneously since 1999 BBANC (Building materials sertification centre; since 2008 - Inspecta AS) glass expert.

Autors of 23 scientific publications.

vasilijsa@vss.lv

Alona Gabrene. 2012 - Mg.sc.ing., PhD student at Riga Technical University.

Work experience - since 2012 - Riga Technical University, Institute of Silicate Materials - research scientist, lecturer.

Co-author of 7 scientific publications; supervisor of bachelor students. agabrene@ktf.rtu.lv

Ieva Ose. B. Sc student, Riga Technical University, Insitute of Silicate Materials. I. Ose is 4 th year student of chemical engineering study programms at Faculty of Material Science and Applied Chemistry, RTU. Her scientific interests is connected with raw materials of Latvia.

ieva.ose@rtu.lv

Janina Setina, Vasilijs Akishins, Alona Gabrene, Ieva Ose. Investigation of Latvian Deposit Quartz Sand as Fine Additives in Concrete Latvian quartz sand from deposits Bale (Devonian period) and Skudras (Jurassic period) was examined. Correlations between the grinding time (4 and 6 hours in the aquatic environment) - dispersion - and grain specific surface area of quartz sand were determined. Specific surface area of grains after grinding significantly increased to $3.19 \mathrm{~m}^{2} / \mathrm{g}$, and was more than the specific surface area $\left(0.91 \mathrm{~m}^{2} / \mathrm{g}\right)$ of sand power used in the production of concrete.

SEM microphotographs of sand ground for 4 and 6 hours showed placoid grains that simulated the quartz crystal structure.

The nature and course of development of adsorption and desorption curves of milled quartz sand in practice are the same; hysteresis loop indicates particle crystallinity.

The dispersion of sand from both deposits after grinding in water in different modes is the same, i.e., the average grain size after 4 hours of treatment is in the range of $16 \ldots 19 \mu$, after 6 hours $12 \ldots 14 \mu$.

The pozzolanic activity test for the evaluation of ground sand reactivity was carried out. The pozzolanic activity of sand from Bale and Skudras deposits increased with an increase in the specific surface area. The sand of Skudras deposit is characterized by a higher pozzolanic activity. The small increase in reactive $\mathrm{CaO}$ in the period from 3 to 14 days shows that the reaction is capable of performing the silica gel layer formed in 3-7 days, and due to agglomeration of gel particles the reaction with alkali in future is limited.

The study of morphology and crystalline phases for cement paste with ground Latvian sand during the hydration process has shown that $12 \ldots 14 \mu$ disperse sand acts as a pore filler and as a pozzolanic additive in cement stimulating the formation of calcium silicate hydrate.

Янина Сетиня, Василий Акишин, Алёна Габрене, Иева Осе. Кварцевый песок латвийских месторождений как мелкодисперсная добавка в бетон

В данной статье рассмотрены латвийские кварцевые пески месторождений Балэ (девонский период) и Скудра (юрский период). Определена взаимосвязь между временем помола (4 и 6 часов в водной среде), дисперсностью и удельной площадью поверхности зерен кварцевого песка. Удельная площадь поверхности значительно увеличилась после измельчения - до 3.19 м²/г и является больше удельной площади поверхности песочного порошка $\left(0.91 \mathrm{~m}^{2} / \Gamma\right)$, используемого в производстве бетона.

На СЭМ микрофотографиях измельченного песка (4 и 6 часов) наблюдаются плоские зерна, имитирующие кристаллическую структуру кварца.

Природа и характер кривых адсорбции и десорбции измельченного кварцевого песка месторождений Балэ и Скудра похожа, вид петли гистерезиса указывает на кристалличность частиц. 
Дисперсность песка с обоих месторождений после измельчения в воде в различных режимах аналогична, т.е. средний размер зерен после 4 часов обработки находится в диапазоне 16 .. $19 \mu$ м, через 6 часов - 12 .. $14 \mu$ м.

Для оценки реактивной способности молотого песка определена пуццолановая активность. Пуццолановая активность песка месторождений Балэ и Скудра увеличивается с увеличением удельной площади поверхности, т.е. дисперсности. Песок месторождения Скудра характеризуется более высокой пуццолановой активностью. Небольшое увеличение реактивной способности $\mathrm{CaO}$ в период от 3 до 14 дней показывает, что способный реагировать гелеобразный слой $\mathrm{SiO}_{2}$ на поверхности зерен песка образуется в течение 3-7 дней и в результате аггломерации частиц реакция со щелочью в дальнейшем ограничена.

Изучение морфологии и кристаллических фаз цементных паст с измельченным песком латвийских месторождений в процессе гидратации показали, что дисперсный (12 .. 14 мм) песок действует как наполнитель пор, а также как пуццолановая добавка в цемент, способствующая образованию гидросиликатов кальция. 